\title{
CENTRAL BANKERS AND CENTRAL BANK INDEPENDENCE
}

\author{
Miroslav Beblavy
}

\begin{abstract}
This paper uses results of a questionnaire survey to look at how central bankers in the Czech Republic, Hungary, Poland and Slovakia view various criteria of central bank independence and compares their responses with central bankers in industrial countries. Central bankers from both groups agree very strongly on the importance of two pillars of central bank independence: goal independence and freedom to implement these goals, together with a system of how credit is granted by a central bank to a government that gives the central bank powers to determine terms and limits the extent of such credit. Based on the responses, the paper also identifies some weaknesses of the most frequently used indices of central bank independence and makes recommendations on how to improve them.
\end{abstract}

\section{INTRODUCTION}

In 1994, Masciandaro and Spinelli (1994) asked ten central banks in industrial countries to assess importance of individual factors contributing to central bank independence. They published their findings in the Scottish Journal of Political Economy. ${ }^{1}$ This paper replicates the research for four countries of Central Europe - the Czech Republic, Hungary, Poland and Slovakia. ${ }^{2}$

Its objective is to assess whether there is consensus on certain issues between the bankers in Central Europe after a decade of transition, in what respects is this consensus shared with the central banks of ten major industrial countries and how can these differences and similarities be explained. However, the

\footnotetext{
${ }^{1}$ The banks received questionnaires listing seven criteria of political independence and seven criteria of economic independence, based on the Grilli, Masciandaro and Tabellini (1991) index of central bank independence. The banks were to rank each criterion from 0 to 1 based on its importance ( 0 the least important) and to state whether anything important is missing. Masciandaro and Spinelli (1994) published the average values for each criterion.

${ }^{2}$ Senior management of each central bank was asked to fill in a questionnaire with questions identical to those posed in the Masciandaro and Spinelli paper. The answers were given by vicegovernors of respective banks. To make things simpler, the values to be awarded to each criterion are not 0 to 1 , but 0 to 10 . Accordingly, the values in the original survey were recalculated to reflect this range.
}

* University of St Andrews and National Bank of Slovakia, Bratislava 
ultimate purpose of the paper is to contribute to assessment of criteria used in determining central bank independence rankings in general and in transition countries in particular. Masciandaro and Spinelli (1994) use criteria developed by Grilli et al. (1991), which, together with Cukierman (1992), consequently became two of the benchmark indices used by many others in further worke.g. Romer and Romer (1997), Keefer and Stasavage (1999) and Moser (1999). They were also used by critics of theories of central bank independence-e.g. Forder (1996, 1999) and Mangano (1998).

Section II presents the relevant data and methodology. Section III explores two pillars of central bank independence on which all central bankers strongly agree. It then examines several criteria that are badly or imprecisely phrased and concludes with a review of additional criteria proposed by central bankers in transition countries. Based on the results of Section III, Section IV analyses strengths and weaknesses of the two most prestigious indices-Grilli et al. (1991) and Cukierman (1992). It also makes several recommendations concerning central bank independence indices, particularly on addition and variable weights of some criteria and on better clarification of other criteria.

\section{Methodology And DATA}

In the original Masciandaro and Spinelli (1994) paper, ten central banks from industrial countries were sent questionnaires listing seven criteria of political independence and seven criteria of economic independence, based on the Grilli, Masciandaro and Tabellini (1991) index of central bank independence. ${ }^{3}$ The banks were to rank each criterion from 0 to 1 based on its importance $(0$ the least important) and to state whether anything important is missing. Masciandaro and Spinelli then published the average values for each criterion, together with an analysis of the data.

In replicating the experiment in Central Europe, deputy governors of central banks in the Czech Republic, Hungary, Poland and Slovakia were asked to fill in a questionnaire with questions identical to those posed in the Masciandaro and Spinelli paper. ${ }^{4}$ To make things numerically simpler, the values to be awarded to each criterion are not 0 to 1 , but 0 to 10 . Accordingly, the values in the original survey were recalculated to reflect this range.

The results of the survey are presented in Table 1 . The first column contains individual values from central bankers in Central Europe. The second column contains the mean of these values and the third one, the standard deviation. The fourth column contains the mean of responses of central banks from industrialised countries and the difference between the means of values provided by central banks in transition and industrialised countries is in the last column.

\footnotetext{
${ }^{3}$ see Table 1 for the list of criteria.

${ }^{4}$ This was done in a personal meeting with the exception of Poland, where it was handled via mail.

(C) Scottish Economic Society 2003
} 
TABLE 1

Importance of selected criteria of central bankers according to central bankers

\begin{tabular}{|c|c|c|c|c|c|}
\hline Values & $\begin{array}{l}\text { Individual } \\
\text { values: } \\
\text { Central } \\
\text { Europe }^{1}\end{array}$ & $\begin{array}{l}\text { Mean: } \\
\text { Central } \\
\text { Europe }\end{array}$ & $\begin{array}{c}\text { Standard } \\
\text { deviation: } \\
\text { Central } \\
\text { Europe }\end{array}$ & $\begin{array}{c}\text { Mean: } \\
\text { industrial } \\
\text { countries }\end{array}$ & $\begin{array}{l}\text { Difference } \\
\text { between the } \\
2 \text { means }\end{array}$ \\
\hline
\end{tabular}

\section{Political independence}

1. CB governor not appointed $\quad 10,10,6,3 \quad 7.25 \quad 2 \quad 5-2.25$ directly by government

2. CB governor appointed for more $10,8,5,5 \quad 7$ than 5 years

3. Rest of the board not appointed $10,10,5,3$ directly by the government

4. No govt. representative on the board

5. No government approval of monetary policy

6. Requirement in the $\mathrm{CB}$ law that $\mathrm{CB}$ pursue monetary stability

7. Provisions in the CB law on conflict resolution

$\begin{array}{lclcc}8,8,0,0 & 4 & 2 \cdot 7 & 6 & -2 \\ 10,10,10,10 & 10 & 0 & 9 & 1 \\ 10,9,5,0 & 6 & 2 \cdot 6 & 9 & -3 \\ 10,0,0,0 & 2 \cdot 5 & 2 \cdot 9 & 7 & -4 \cdot 5\end{array}$

\section{Economic independence}

CB credit to the govt.

1. Not automatic

2. Market interest rate

3. Limited duration

$10,10,10,10 \quad 10$

$10,10,10,5 \quad 8.75$

4. Limited amount

$10,10,10,8$

$10,10,10,8$

5. CB not in the primary govt. debt market

6. Interest rates set by $\mathrm{CB}$

7. Bank supervision outside $\mathrm{CB}$
$1 \cdot 4$

6

1

$-4 \cdot 5$

Note:

${ }^{1}$ Values in individual rows are arranged in the descending order, not by respondents.

Source: Author based on questionnaire responses, Masciandaro and Spinelli (1994).

\section{ANALYSIS OF RESPONSES}

\section{Two pillars of central bank independence}

Central bankers in Central Europe feel very strongly about the following four lynchpins of central bank independence. ${ }^{5}$ Generally, surveyed central bankers from transition countries gave 10 to these criteria, suggesting the strength of consensus. Their view is also shared by the central bankers from industrialised countries based on Masciandaro and Spinelli (1994). First of all, no governmental approval of monetary policy should be required. This criterion can be roughly identified with goal independence, an ability of central bank to set final goals of monetary policy (see Debelle and Fischer, 1995). Secondly, CB should set discount and other major interest rates. This criterion, on the other

\footnotetext{
${ }^{5}$ Definition of consensus used here is that all or all but one values fall within a range of 2 and their mean is at least 9 . 
hand, can be approximately identified with instrument independence (freedom to choose means to achieve a given monetary policy end (ibid.)). Thirdly, there should be restrictions on $\mathrm{CB}$ credit to government. This comprises four criteria of economic independence concerning duration, amount, interest rate and automatic nature of the central bank credit to the government. And finally, CB should not be active in the primary market for government debt. Participation of the central bank in the primary market could serve to circumvent limits on the direct credit and also would distort the market.

Based on these results, two pillars of true independence as perceived by central bankers of surveyed transitional and industrial countries can be identified: goal independence with freedom to implement the chosen goal and a well-defined relationship of the central bank and the government concerning credit to the government, which gives the central bank the power to determine the terms of the relationship and limits the extent of $\mathrm{CB}$ assistance to the budget

\section{Problems with phrasing of criteria}

Three criteria were identified during the survey as badly or imprecisely phrased: that no representative of government be present on the central bank board, a requirement that central bank pursues monetary stability and a requirement that the term of central bank governor is longer than five years. All of these criteria show a wide spread in values. Based on the questionnaire, a large part of this is because of the imprecise nature of both criteria. In the case of the government representative, it is important whether the representative has an advisory position or a vote. For example, a central banker from a transition country stipulated that in the former case, the value should be 10 and in the latter 0. Another one offered an explanation of why a criterion of extreme importance in industrial countries (it was ranked as first in the political criteria in Masciandaro and Spinelli, 1994) was considered not that important in transition countries. It is the criterion of whether the central bank law contains a provision requiring the central bank to pursue monetary stability. A central banker from a transition country rated this criterion 0 , but noted that the requirement should be for price stability. Another one noted that while giving this criterion 5 points, it would receive 10 if it were for price stability. Consequently, it can be noted that if the criterion were price stability, it would be among the very important criteriacreating a third pillar of clearly-defined mandate for a central bank. The insistence on the price stability criterion can be explained by the fact that all four economies are very small and very open and so the external monetary stability (stable exchange rate) and internal monetary stability (low inflation) can easily be conflicting, weakening the central bank mandate to pursue low inflation.

The same is true to a certain extent for the length of a governor's term. The criterion was originally introduced in this form to measure whether the term of the $\mathrm{CB}$ governor is longer than the electoral cycle, which lasts five years in many countries (Grilli, Masciandaro and Tabellini, 1991). However, in all four countries in our survey, the length of cycle is four years. Therefore, five years is 
enough to fulfil the raison detre of this criterion and this is reflected in relatively low values given to this criterion in its present form.

\section{Additional criteria}

While the central banks in Masciandaro and Spinelli (1994) considered the 14 criteria to be sufficient, central bankers from transition countries proposed some additions to the criteria, reflecting their experience of transition. There were five proposed additions, which can be divided into three groups.

The first group reinforces the first pillar of $\mathrm{CB}$ independence that measures goal and instrument independence. There is only one proposal in this category - a criterion measuring specifically whether the central bank can determine the exchange rate policy. The second group reinforces the second pillar of $\mathrm{CB}$ independence that restricts the central bank financing of the budget. One proposal introduces a criterion of whether there are any (quasi) fiscal measures (subsidies) by the central bank. Another proposes banning the direct credit altogether. The third group introduces a new pillar-budget independence. This contains criteria such as 'who approves the budget' (in all four countries, it is the bank board) or whether the law is specific on how CB profit should be distributed (see below).

\section{IMPLICATIONS FOR CENTRAL BANK INDEPENDENCE INDICES}

This section deals with the indices of central bank independence, which are most frequently used in the literature: Grilli et al. (1991) and Cukierman (1992), comparing them with the findings of this paper. The most important indicators of robustness of Grilli et al. (1991) and Cukierman (1992) are the focus on goal and instrument independence and focus on central bank financing of the government. The analysis of their most important shortcomings and recommendations for improvement follow.

The first major shortcoming is a lack of precision in defining certain criteria, particularly concerning the objective of monetary policy, the presence of government representative on the board and the length of term of governor and other bank officials (see above). These invalidate the usefulness of these criteria for measurement of central bank independence. Formulation of these criteria should also be based on the rationale for their inclusion in the ind.

As far as length of term is concerned, those constructing the index should clarify whether they believe (as Cukierman, 1992, and Grilli et al., 1991 do) that the independence of central bank increases not in a linear relationship with the length of term of policy-makers in the central bank, but that it is only important for the length of term to be greater than the electoral cycle. In that case, criteria should be constructed accordingly. If they believe in the linear fashion, they should also act accordingly.

In the case of a government representative on the board, the criterion should distinguish whether the issue is the physical presence of a government 
representative in the board meetings or in the vote the representative can use to influence actual outcomes. Values should be assigned accordingly.

A similar approach applies to the issue of whether monetary/price stability should be in the central bank law as the final goal. Two factors have to be taken into account when considering this issue. First of all, a goal of monetary/price stability protects the central bank from political or other pressures aimed at using the short-term Phillips curve to increase output and employment above their natural rate. This is true for both monetary and price stability. However, in the case of an open economy, only price stability provides a clear goal. Monetary stability does not provide clear guidance, whether external or internal stability should have priority. Any index should state its position on the issue and be constructed accordingly.

The second major problem with the most prestigious indices is omission of some extremely important elements of central bank (in)dependence, namely the exchange rate management and budget independence. For a small open economy, framework for exchange rate management is of great importance for actual central bank independence, but this is not reflected in the indices. One can find an explanation in Mas (1994, p. 16), which claims that in no country 'has the exchange rate policy been turned over entirely to the central bank'. Even though this statement is not true, it provides an explanation-if central bank independence in exchange rate policy is extremely rare, creators of central bank independence indices did not include it into indices as it would have little explanatory power. In the group of countries that this paper is concerned with, however, complete central bank autonomy in determining the exchange rate policy is not rare. In Hungary and Poland, it is the government that determines the exchange rate regime. On the other hand, central bank statutes in the Czech Republic and Slovakia state identically that the central bank 'shall ... state the exchange rate of the [Czech/Slovak] crown in relation to foreign currencies' (Slovak Republic, 1992; Czech Republic, 1993). This autonomy has been extensively used in practice by both central banks, several times against the express wishes of the government.

Budget independence for a central bank has two dimensions that can be important for central bank independence. First of all, a large part of the budget of many central banks is spent on execution of monetary policy, particularly if the bank is sterilising significant financial flows or intervening in the foreign exchange markets. If the budget is determined by the government or parliament, there is significant scope for influencing the actual monetary policy execution. Relevance of this issue depends on the particular nature of a given economy and the way its monetary system is set, but it is likely to be relevant across the board. Similar argument can be applied to the personnel budget or budget for running costs - if the government or parliament determine these, there is a significant scope for influencing the bank officials. On the other hand, there is the issue of democratic delegation, control and accountability. A central bank uses public resources, in the form of budget subsidies or seigniorage revenues. Therefore, a trade-off between independence and accountability is necessary. 
Both criteria mentioned above also illustrate, however, another important issue-the different importance of some criteria for various countries. Importance of exchange rate independence for a central bank rises with openness of the economy and it is, therefore, very difficult to pinpoint accurately. Whether the ECB can determine its exchange rate policy is much less important for its independence than is the case with the National Bank of Slovakia. Budget independence is much more important in countries where turbulent economic and political climate makes it easier for politicians to politically manipulate the central bank budget without public outcry. Therefore, indices should take into account this factor and consider assigning different weights to these factors in different groups of countries.

\section{CONCLUSION}

This paper looks at how central bankers in Central Europe view various criteria of central bank independence and compares their positions with central bankers in industrial countries. Central bankers in Central Europe, together with central bankers from industrial countries, agree very strongly on the importance of two pillars of central bank independence, which can be roughly identified with (i) goal independence and freedom to implement these goals and (ii) a system of how credit is granted by a central bank to a government that gives the central bank powers to determine terms of the relationship and limits the extent of such credit.

Central bankers in Central Europe propose additional criteria for measuring central bank independence. These criteria either further clarify the two pillars of independence or propose a new one-budget independence, which would measure how vulnerable a central bank is from the financial point of view (CB budget decisions and decisions about distribution of central bank profit).

Results of the survey include their comparison with Masciandaro and Spinelli (1994) and analysis of both points both to robustness of the two most prestigious indices - Grilli et al. (1991) and Cukierman (1992) - and to their substantial weaknesses. The robustness comes from focus on goal and instrument independence and on how the central bank financing of the government is solved. The most important shortcomings of the two most prestigious indices are lack of precision in defining certain criteria, particularly concerning the objective of monetary policy, the presence of government representative on the board and the length of term of governor and other bank officials. Criteria other than those related to two pillars of central bank independence should be defined in a very precise manner and related to the rationale for their inclusion in the index.

The other major shortcoming is in omission of some extremely important elements of central bank (in)dependence, namely the exchange rate management and budget independence. However, what is also important is that there are criteria (including exchange rate autonomy and budget independence) that have variable importance across countries due to different cultural and economic characteristics. 


\section{REFERENCES}

Berger, H. and De HAan, J. (1999). A state within the state? An event study on the Bundesbank. Scottish Journal of Political Economy, 46, 1.

Czech RePublic (1993). Law on the Czech National Bank. Collection of Laws of the Czech Republic No. 6/1993, Prague: Ministry of Justice of the Czech Republic.

Debelle, G. and FisCher, S. (1995). How independent should a central bank be? In J. C. Fuhrer (ed.), Goals, Guidelines and Constraints Facing Monetary Policymakers. Federal Reserve Bank of Boston, Conference Series No. 38, pp. 195-221.

FORDER, J. (1996). On the assessment and implementation of institutional remedies. Oxford Economic Papers, 48, pp. 39-51.

FORDER, J. (1998). Central bank independence-conceptual clarifications and interim assessment. Oxford Economic Papers, 50, pp. 307-34.

Grilli, V., Masciandaro, D. and Tabellini, G. (1991). Political and monetary institutions and public financial policies in the industrial countries. Economic Policy, 13, pp. 341-92.

KeEFer, P. and Stasavage, D. (2000). Bureaucratic delegation and political institutions: when are independent central banks irrelevant? World Bank Working Paper, No. 2356. Washington, DC: World Bank.

MANGANO, G. (1998). Measuring central bank independence: a tale of subjectivity and its consequences. Oxford Economic Papers, 50, pp. 468-92.

MAS, I. (1994). Central bank independence: a critical view from a developing country perspective. Policy Research Working Paper, No. 1356, Washington, DC: World Bank.

Masciandaro, D. and Spinelli, F. (1994). Central banks independence: institutional determinants, rankings and central bankers views. Scottish Journal of Political Economy, 41, 4, pp. 434-43.

Moser, P. (1999). Checks and balances, and the supply of central bank independence. European Economic Review, 43, 8, pp. 1569-93.

ROMER, CH. and ROMER, D. (1997). Institutions for monetary stability. In Reducing Inflation: Motivation and Strategy. NBER Studies in Business Cycles, 30. Chicago and London: University of Chicago Press, pp. 307-29.

Slovak Republic (1992). Law on the National Bank of Slovakia. Collection of Laws of the Slovak Republic No. 566/1992. Bratislava: Ministry of Justice of the Slovak Republic.

Date of receipt of final manuscript: 31 January 2002. 